Syntax Literate : Jurnal Ilmiah Indonesia p-ISSN: 2541-0849

e-ISSN : 2548-1398

Vol. 6, No. 12, Desember 2021

\title{
DAMPAK MAKRO EKONOMI TERHADAP RETURN SAHAM DENGAN PROFITABILITAS SEBAGAI INTERVENING DAN INFLASI SEBAGAI MODERASI
}

\section{Rizki Wulandari, Sri Hermuningsih, Gendro Wiyono}

Magister Manajemen Universitas Sarjanawiyata Tamansiswa Yogyakarta, Indonesia

Email: 2kk.wulandari@gmail.com, hermun_feust@yahoo.com,

gendrowiyono@ustjogja.ac.id

\section{Abstrak}

Perekonomian Indonesia dan dunia pada tahun 2020 mengalami perlambatan yang cukup signifikan akibat adanaya pandemi covid-19. Faktor makro ekonomi merupakan faktor yang terdampak paling awal akibat pandemi ini. Untuk meneliti keterkaitan antara pandemi covid-19 dan makro ekonomi, maka penelitian ini dibuat dengan tujuan menguji secara empiris pengaruh nilai tukar dan suku bunga terhadap return saham dengan profitabilitas sebagai variabel intervening serta inflasi sebagai varibael moderasi pada perusahaan sektor consumer goods yang terdaftar di bursa efek Indonesia tahun 2020. Penelitian ini menggunakan metode analisis deskriptif dan metode analisis inferensial. Untuk melakukan analisis inferensial pada penelitian ini, alat analisis yang digunakan adalah Partial Least Square (PLS) yaitu SEM berbasis varians, dengan software SmartPLS 3.2.8. Analisis jalur dilakukan dengan menghitung pengaruh langsung, pengaruh tidak langsung, dan pengaruh total. Tingkat kesalahan pada penelitian ini adalah 5\%, atau dengan kata lain memiliki tingkat kepercayaan sebesar $95 \%$. Sampel pada penelitian ini sebanyak 23 perusahaan yang didapatkan dengan metode purposive sampling. Hasil penelitian menunjukkan bahwa suku bunga dan nilai tukar tidak berpengaruh terhadap profitabilitas. Begitu pula perofiabilitas tidak berpengaruh terhadap return saham. Suku bunga dan nilai tukar berpengaruh negatif signifikan terhadap retun saham. Profitabilitas sebagai variabel intervening tidak mampu memediasi pengaruh nilai tukar dan suku bunga terhadap return saham. Begitu pula dengan inflasi yang tidak mampu memoderasi pengaruh profitabilitas terhadap return saham.

Kata Kunci: nilai tukar; suku bunga; profitabilitas; inflasi; return saham; makro ekonomi.

\section{Abstract}

The economy of Indonesia and the world in 2020 experienced a significant slowdown due to the COVID-19 pandemic. Macroeconomic factors are the factors that are most affected by this pandemic. To examine the relationship between the covid-19 pandemic and macroeconomics, this study was made with the aim to empirically examine the

\footnotetext{
How to cite:

Wulandari. R., Sri Hermuningsih \& Gendro Wiyono (2021) Dampak Makro Ekonomi Terhadap Return Saham Dengan Profitabilitas Sebagai Intervening Dan Inflasi Sebagai Moderasi. Syntax Literate: Jurnal Ilmiah Indonesia, 6(12). http://dx.doi.org/10.36418/ Syntax-Literate.v6i12.5053

E-ISSN: 2548-1398

Published by: $\quad$ Ridwan Institute
} 
effect of exchange rates and interest rates on stock returns with profitability as an intervening variable and inflation as a moderating variable in consumer goods sector companies listed on the Indonesian stock exchange in 2020. This study uses descriptive analysis methods and inferential analysis methods. Inferential analysis was performed using the Partial Least Square (PLS) method, namely variance-based SEM using the SmartPLS 3.2.8 software. Path analysis is done by calculating the direct effect, indirect effect, and total effect. This study has a standard error of 5\%, or in other words it has a 95\% confidence level. The sample in this study were 23 companies obtained by purposive sampling method. The results showed that interest rates and exchange rates had no effect on profitability. Likewise perofiability has no effect on stock returns. Interest rates and exchange rates have a significant negative effect on stock returns. Profitability as an intervening variable is unable to mediate the effect of exchange rates and interest rates on stock returns. Likewise, inflation is not able to moderate the effect of profitability on stock returns.

Keywords: exchange rate; interest rate; profitability; inflation; stock return; macro economi.

Received: 2021-11-20; Accepted: 2021-12-05; Published: 2021-12-20

\section{Pendahuluan}

Laju pertumbuhan ekonomi memiliki makna penting bagi masyarakat, pemerintah dan para pengusaha, serta investor dalam mendukung berkembangnya suatu negara. Perekonomian Indonesia pernah terpuruk saat krisis ekonomi pada tahun 1998 dan kemudian diikuti oleh krisis dunia tahun 2008. Pada tahun 2020, seluruh dunia terdampak oleh suatu bencana yaitu pandemi covid-19 yang disebebkan oleh sebuah virus yang pertma kali ditemukan di Wuhan China bernama virus corona. Pandemi virus Covid-19 ini memberikan tekanan berat pada semua bidang dari bidang kesehatan hingga pada bidang perekonomian. Menurut pemaparan Muhadjir Effendy, krisis ekonomi yang terjadi saat ini di Indonesia sebagai imbas pandemi Covid-19 lebih parah dari krisis ekonomi yang terjadi pada 1998 (Wicaksono, 2020). Hal ini terjadi karena untuk mencegah penyebaran wabah yang semakin meluas diharuskan bagi setiap orang untuk membatasi aktivitas di luar ruangan sehingga aktivitas perekonimian pun mengalami hambatan dalam perjalanannya. Faktor - faktor makro ekonomi adalah yang terdampak paling awal saat pandemi ini meluas ke seluruh belahan dunia. Fundamental ekonomi makro terdiri dari empat indikator yaitu inflasi, suku bunga, nilai tukar USD, dan jumlah uang beredar (Hermuningsih, 2019). Dari keempat indikator tersebut, akan diteliti 3 indikator yaitu nilai tukar, suku bunga, dan inflasi.

Pada bulan Maret 2020 kasus pertama covid-19 diumumkan di Indonesia. Seketika itu pula terjadi berbagai gejolak terutama pada bidang perekonomian. Salah satu faktor makro ekonomi yang langsung terdampak adalah nilai tukar rupiah atau kurs rupiah 
terhadap US Dollar. Nilai tukar rupiah terhadap dolar Amerika Serikat sempat melemah dari kisaran Rp13.000 di bulan Februari ke titik terendahnya pada kisaran Rp16.000 per dolar AS di minggu terakhir bulan Maret 2020. Pelemahan ini berkaitan dengan sikap pesimistis pelaku bisnis dan ekonomi terhadap kebijakan pemerintah Indonesia dalam menangani Covid-19 (Kartikaningsih et al., 2020). Nilai tukar (kurs) merupakan salah satu faktor makro ekonomi yang mempengaruhi aktivitas perdagangan saham karena pergerakan kurs yang tidak stabil dapat mengurangi kepercayaan investor lokal maupun investor asing terhadap kondisi perekonomian Indonesia. Hal ini tentu akan menimbulkan dampak negatif terhadap perdagangan saham di pasar modal. Investor asing akan cenderung melakukan penarikan modal sehingga terjadi Capital of Flow dan hal ini akan berimbas pada menurunnya tingkat return yang akan dibagikan (Suriyani \& Sudiartha, 2018). Selain itu, pelemahan kurs rupiah terhadap dolar Amerika Serikat seperti yang terjadi saat ini berpotensi menaikkan biaya produksi sehingga profitabilitas akan menurun. Penurunan profitabilitas akan berdampak pada harga saham dan mempengaruhi return yang diharapkan oleh para investor.

Pada bidang kebijakan moneter, BI telah menurunkan suku bunga acuan sebesar 100 basis poin (bps) secara kumulatif pada bulan Februari, Maret, Juni, dan Juli 2020 menjadi 4,25\% untuk menjaga likuiditas (Junaedi et al., 2020). Suku bunga acuan yang digunakan saat ini adalah BI-7 Day Reverse Repo Rate (BI7DRR). Pada kuartal pertama semenjak diumumkannya kasus pertama covid-19 di Indonesia memang menjadi masa terberat bagi perekonomian Indonesia. Berbagai upaya dan stimulus diberikan oleh pemerintah untuk terus mendongkrak perekonomian. Dalam kebijakan moneter, pemerintah dapat memanfaatkan bank sentral untuk membuat sebuah kebijakan dengan tujuan untuk mengendalikan perekonomian. Salah satunya adalah dengan menurunkan tingkat suku bunga acuan BI secara bertahap dan terus menerus. Hingga November 2020 suku bunga BI 7-Day Reverse Repo Rate (BI7DRR) berada pada angka 3,75\%. Disisi lain, penurunan suku bunga dapat memberikan dampak positif bagi semua sektor karena penurunan suku bunga akan menurunkan modal perseroan jika melakukan ekspansi usaha melalui kredit. Kemungkinan ekspansi perusahaan yang lebih luas dapat meningkatkan profitabilitas dan profitabilitas yang meningkat dapat menigkatkan harga saham. Selain itu, turunnya tingkat suku bunga dapat menarik investor untuk berinvestasi pada saham dibandingkan dengan investasi bebas risiko seperti deposito dengan harapan mendapat return yang lebih tinggi (Akbar \& Afiezan, 2018).

Faktor makro ekonomi lain yang terdampak pandemi covid-19 adalah inflasi. Badan Pusat Statistik (BPS) melaporkan bahwa inflasi tahun 2020 sebesar 1,68\% adalah yang terendah sepanjang sejarah pencatatan inflasi oleh BPS (Fauzia, 2021). Inflasi dapat berdampak positif maupun negatif tergantung tingkat inflasi yang terjadi. Inflasi yang terlalu tinggi dapat menyebabkan keterpurukan pada perekonomian secara keseluruhan karena berimbas pada kebangkrutan perusahaan. Peningkatan inflasi akan menyebabkan 
kenaikan harga barang-barang dan akan berdampak pada peningkatan biaya produksi (Hermuningsih et al., 2018). Inflasi yang tinggi akan menjatuhkan harga saham di pasar, sedangkan tingkat inflasi yang sangat rendah akan mengakibatkan pertumbuhan ekonomi menjadi sangat lamban, dan pada akhirnya harga saham juga akan bergerak dengan lamban (Wiska \& Resty, 2020). Penurunan tingkat inflasi yang terjadi tahun 2020 lebih mengarah pada signal negatif akan melambannya perekonomian akibat dampak dari pandemi covid19.

Pengaruh faktor-faktor makro ekonomi terhadap harga saham telah diteliti sebelumnya oleh beberapa peneliti namun masih mendapatkan hasil yang berbeda. Penelitian yang dilakukan oleh Khan (2019), Hakim \& Martono (2019), Al-Abdallah (2017) serta Siregar \& Diana (2019) menunjukkan bahwa nilai tukar dan suku bunga memiliki pengaruh yang signifikan terdadap return saham. Namun ada perbedaan hasil penelitian yang dilakukan oleh Fadlilah \& Hermuningsih (2017), Hendrawan \& Avitianti (2018), Alam (2020), dan Saputri et al. (2019) yang menyimpulkan bahwa tidak ada pengaruh signifikan antara suku bunga dan nilai tukar terhadap retun saham. Karena masih adanya perbedaan hasil dari penelitian terdahulu, maka peneliti akan melakukan penelitian kembali terhadap pengaruh nilai tukar dan suku bunga terhadap return saham namun dengan menambahkan profitabilitas sebagai variabel intervening dan inflasi sebagai variabel moderasi.

Atas berbagai fenomena serta perbedaan hasil penelitian terdahulu, maka peneliti akan melakukan penelitian yang bertujuan untuk mencari bukti empiris pengaruh nilai tukar dan suku bunga terhadap return saham dengan profitabilitas sebagai variabel intervening dan inflasi sebagai variabel moderasi.

\section{Metode Penelitian}

\section{A. Jenis dan Sumber Data}

Penelitian ini menggunakan data sekunder yang diperoleh dari perusahaan yang terdapat dalam Sektor Consumer Good Industry tahun 2019-2020. Sumber data dapat diperoleh dari Laporan Triwulan perusahaan yang dipublikasikan oleh BEI.

\section{B. Populasi dan Sampel}

Populasi dalam penelitian ini adalah 51 perusahaan. Sampel penelitian ini adalah perusahaan sektor Consumer Goods Industry yang terdatar di BEI tahun 2019 - 2020. Metode pemilihan sampel menggunakan metode purposive sampling. Kriteria responden dalam penelitian ini adalah perusahaan yang terdaftar dalam sektor Consumer Good Industry yang listing di BEI dari tahun 2019-2020, melaporkan laporan triwulan secara berturut-turut dari triwulan 1 hingga triwulan 4, dan tidak memliki nilai return saham 0 . Dari hasil pemilihan sampel didapatkan sebanyak 23 perusahaan yang memenuhi kriteria purposive sampling. 


\section{Teknik Analisis Data}

\section{Analisis Deskriptif}

Dalam penelitian ini menggunakan analisis deskriptif guna mengetahui gambaran terkait sampel yang diperoleh. Analisis deskriptif digunakan untuk mendiskripsikan data secara sederhana melalui mean (rata-rata), standar deviasi, nilai tertinggi dan nilai terendah. Pengolahan data dilakukan dengan bantuan program SPSS.

\section{Analisis Inferensial}

Guna melakukan analisis inferensial dari penelitian ini, alat analisis yang digunakan adalah Patial Least Square (PLS), yaitu SEM yang berbasis variance, dengan software SmartPLS 3.2.8. Tahap pengujian PLS sebagai berikut:

\section{a) Uji Model Fit}

Pengujian model fit dilakukan dengan cara melihat hasil estimasi output SmartPLS, kemudian dibandingkan dengan kriteria seperti penjelasan pada tabel berikut ini.

\section{Tabel 1}

\section{Kriteria Penilaian Model Fit}

\begin{tabular}{|c|c|c|}
\hline $\begin{array}{c}\text { Fit } \\
\text { Summary }\end{array}$ & Estimated & Penjelasan dan Kriteria \\
\hline SRMR & $\begin{array}{c}\text { Hasil dilihat } \\
\text { pada output } \\
\text { SmatrtPLS } \\
\text { setelah di } \\
\text { eksekusi } \\
\text { PLS Algorithm }\end{array}$ & $\begin{array}{l}\text { Standardized Root Mean Square Residual (RMSR) } \\
\text { adalah ukuran nilai absolut rata-rata residu kovarians, } \\
\text { berdasarkan transformasi matriks kovariansi sampel } \\
\text { dan matriks kovariansi yang diprediksi menjadi } \\
\text { matriks korelasi. Menilai besarnya rata-rata perbedaan } \\
\text { antara korelasi yang diamati dan yang diharapkan } \\
\text { sebagai ukuran mutlak kriteria (model) yang sesuai. } \\
\text { Nilai kurang dari } \mathbf{0 , 1 0} \text { dianggap sesuai dan } \\
\text { merupakan goodness of fit measure untuk PLS-SEM } \\
\text { yang dapat digunakan untuk menghindari } \\
\text { misspecification model (Henseler } \text { et al., 2014). }\end{array}$ \\
\hline $\begin{array}{l}\text { d_ULS } \\
\text { d_G }\end{array}$ & $\begin{array}{l}\text { Hasil dilihat } \\
\text { pada output } \\
\text { SmatrtPLS } \\
\text { setelah di } \\
\text { eksekusi } \\
\text { PLS Algorithm }\end{array}$ & $\begin{array}{l}\text { d_ULS (jarak Euclidean kuadrat) dan d_G (jarak } \\
\text { geodesik) mewakili dua cara yang berbeda untuk } \\
\text { menghitung ketidaksesuaian. Batas atas interval } \\
\text { kepercayaan harus lebih besar dari nilai asli kriteria } \\
\text { d_ULS dan d_G untuk menunjukkan bahwa model } \\
\text { memiliki "kesesuaian yang baik". Batas atas berada } \\
\text { pada titik 95\%. }\end{array}$ \\
\hline $\begin{array}{c}\text { Chi- } \\
\text { Square }\end{array}$ & $\begin{array}{l}\text { Hasil dilihat } \\
\text { pada output } \\
\text { SmatrtPLS } \\
\text { setelah di } \\
\text { eksekusi } \\
\text { PLS Algorithm }\end{array}$ & $\begin{array}{c}X^{2} \text { Statistik }<X^{2} \text { Tabel, artinya jumlah variabel manifes } \\
\text { dalam model jalur PLS dan jumlah variabel } \\
\text { independen dalam model matriks kovarian tercukupi. }\end{array}$ \\
\hline
\end{tabular}




\begin{tabular}{|c|c|c|}
\hline NFI & $\begin{array}{l}\text { Hasil dilihat } \\
\text { pada output } \\
\text { SmatrtPLS } \\
\text { setelah di } \\
\text { eksekusi } \\
\text { PLS Algorithm }\end{array}$ & $\begin{array}{l}\text { Normed Fit Index (NFI) semakin mendekati NFI nilai } \\
\text { 1, semakin baik kecocokannya. NFI merupakan } \\
\text { ukuran kesesuaian. Semakin besar hasil NFI, semakin } \\
\text { baik model. }\end{array}$ \\
\hline $\begin{array}{l}\text { RMS } \\
\text { Theta }\end{array}$ & $\begin{array}{c}\text { Hasil dilihat } \\
\text { pada output } \\
\text { SmatrtPLS } \\
\text { setelah di } \\
\text { eksekusi } \\
\text { PLS Algorithm }\end{array}$ & $\begin{array}{l}\text { The root mean squared residual covariance matrix of } \\
\text { the outer model residuals (RMS_theta) menilai sejauh } \\
\text { mana residu model luar berkorelasi. Ukuran harus } \\
\text { mendekati nol untuk menunjukkan model yang baik. } \\
\text { RMS_theta dibangun di atas residu outer model, yang } \\
\text { merupakan perbedaan antara nilai indikator yang } \\
\text { diprediksi dan nilai indikator yang diamati. Untuk } \\
\text { memprediksi nilai indikator, penting bagi PLS untuk } \\
\text { mendapatkan nilai variabel laten. Nilai RMS_theta di } \\
\text { bawah 0,12 mengindikasikan model yang pas } \\
\text { (Henseler et al., 2014). }\end{array}$ \\
\hline
\end{tabular}

\section{b) Uji Hipotesis}

Inner Model atau structural model merupakan uji hipotesis yang menggambarkan hubungan dan pengaruh antar variabel laten berdasarkan pada substantive theory. Model persamaannya dapat dituliskan seperti dibawah ini.

$$
\eta=\beta_{0}+\beta \eta+\Gamma \xi+\zeta
$$

Dimana:

$\eta=$ vector endogen (dependen) variabel laten

$\xi=$ vector exogen (independen) variabel laten

$\zeta=$ vector residual

\section{Analisis Mediasi}

Analisis mediasi digunakan untuk mengetahui apakah variabel intervening dalam suatu model penelitian berfungsi sebagai variabel yang mampu meningkatkan pengaruh variabel independen terhadap variabel dependen (Wiyono, 2020). Analisis mediasi pada penelitian ini dilakukan dengan bantuan aplikasi SmartPLS 3.2.8 yang dilakukan dengan melakukan kalkulasi bootstrapping. Hasil kalkulasi bootstraping akan menghasilkan direct effect, total indirect effect dan total effect yang digunakan sebagai penilaian apakah variabel intervening dapat memediasi pengaruh variabel dependen dan independen.

\section{E. Analisis Moderasi}

Variabel moderasi berperanan sebagai variabel yang dapat memperkuat atau memperlemah pengaruh antara variabel independen dengan variabel dependen (Wiyono, 2020). Analisis moderasi digunakan untuk mengetahui apakah variabel 
moderasi dalam suatu model penelitian mampu memperkuat atau memperlemah pengaruh antara variabel independen dan variabel dependen. Analisis moderasi dalam penelitian dilakukan dengan bantuan aplikasi SmartPLS 3.2.8 yang dilakukan dengan melakukan kalkulasi bootstrapping. Hasil kalkulasi bootstraping akan menghasilkan moderating effect.

\section{Hasil dan Pembahasan}

\section{A. Hasil Analisis Deskriptif}

Dari hasil uji analisis deskriptif atas variabel-variabel yang digunakan dalam penelitian ini didapatkan hasil sebagi berikut:

\section{Tabel 2}

\section{Hasil Analisis Deskriptif}

\begin{tabular}{lrrrrr}
\hline Variabel & N & \multicolumn{1}{c}{ Minimum } & Maximum & \multicolumn{1}{c}{ Mean } & Std. Deviation \\
\hline Return & 92 & -0.8441 & 11.6821 & 0.1117575 & 1.2545855 \\
\hline ROE & 92 & -71.9000 & 140.0000 & 15.125022 & 27.7293688 \\
\hline Kurs & 92 & 14105.0000 & 16367.0000 & 14923.000000 & 890.8466031 \\
\hline Bunga & 92 & 3.7500 & 4.5000 & 4.125000 & .2810401 \\
\hline Inflasi & 92 & \multicolumn{7}{c}{ Sumber: hasil olah data SPSS 20 } & 2.4200 \\
\hline \multicolumn{7}{c}{ Sumber }
\end{tabular}

Hasil analisis deskriptif variabel return saham diperoleh nilai tertinggi (max) sebesar 11,682 adalah PT Indofood CBP Sukses Makmur Tbk pada triwulan ke-4, dan nilai terendah $(\mathrm{min})$ sebesar -0.8441 adalah PT Unilever pada triwulan pertama. Analsis deskriptif juga menunjukkan nilai rata-rata sebesar 0,109675 dan standar deviasi sebesar 1.2545855. Hasil tersebut menunjukkan bahwa nilai rata-rata lebih kecil daripada standar deviasi, sehingga mengindikasi hasil yang kurang baik. Hal tersebut dikarenakan standar deviasi adalah perncerminan penyimpangan yang sangat tinggi, sehingga penyebaran data menunjukkan hasil yang tidak normal dan menyebabkan bias.

Hasil analisis deskriptif variabel profitabilitas diperoleh nilai tertinggi ( $\max$ ) sebesar 140 adalah Unilever pada triwulan pertama dan nilai terendah ( $m i n$ ) sebesar 71.9 adalah Martina Beto Tbk pada triwulan ke-4. Analsis deskriptif juga menunjukkan nilai rata-rata sebesar 15,125 dan standar deviasi sebesar 27,7293. Hasil tersebut menunjukkan bahwa nilai rata-rata lebih kecil daripada standar deviasi, sehingga mengindikasi hasil yang kurang baik. Hal tersebut dikarenakan standar deviasi adalah perncerminan penyimpangan yang sangat tinggi, sehingga penyebaran data menunjukkan hasil yang tidak normal dan menyebabkan bias.

Hasil analisis deskriptif variabel nilai tukar diperoleh nilai tertinggi ( $\max$ ) sebesar 16.367 pada triwulan pertama dan nilai terendah $(\mathrm{min})$ sebesar 14.105 pada triwulan ke4. Analsis deskriptif juga menunjukkan nilai rata-rata 14.923 dan standar deviasi 
sebesar 890,846. Hasil tersebut menunjukkan bahwa nilai rata-rata lebih besar daripada standar deviasi, sehingga mengindikasi hasil yang baik. Hal tersebut dikarenakan standar deviasi adalah perncerminan penyimpangan yang sangat tinggi, sehingga penyebaran data menunjukkan hasil yang normal dan tidak bias.

Hasil analisis deskriptif variabel suku bunga diperoleh nilai tertinggi (max) sebesar 3,75 pada triwulan ke-4 dan nilai terendah ( $\min$ ) sebesar 4,5 pada triwulan pertama. Analisis deskriptif juga menunjukkan nilai rata-rata sebesar 4,125 dan standar deviasi sebesar 0,281. Hasil tersebut menunjukkan bahwa nilai rata-rata lebih besar daripada standar deviasi, sehingga mengindikasi hasil yang baik. Hal tersebut dikarenakan standar deviasi adalah perncerminan penyimpangan yang sangat tinggi, sehingga penyebaran data menunjukkan hasil yang normal dan tidak bias.

Hasil analisis deskriptif variabel inflasi diperoleh nilai tertinggi ( $\max$ ) sebesar 2,96 pada triwulan pertama dan nilai terendah ( $\mathrm{min}$ ) sebesar 1,42 pada triwulan ke-4. Analsis deskriptif juga menunjukkan nilai rata-rata sebesar 2,005 dan standar deviasi sebesar 0,586. Hasil tersebut menunjukkan bahwa nilai rata-rata lebih besar daripada standar deviasi, sehingga mengindikasi hasil yang baik. Hal tersebut dikarenakan standar deviasi adalah perncerminan penyimpangan yang sangat tinggi, sehingga penyebaran data menunjukkan hasil yang normal dan tidak bias.

\section{B. Uji Model Fit}

Hasil perhitungan bootstraping uji model fit menghasilkan output sebagai berikut:

Tabel 3

Hasil Uji Model Fit

\begin{tabular}{|c|c|c|c|}
\hline Model Fit Index & Saturated Model & Estimated Model & Cut-off Value \\
\hline SRMR & 0,000 & 0,003 & $<0,10$ \\
\hline d_ULS & 0,000 & 0,000 & $>0,05$ \\
\hline d_G & 0,000 & 0,000 & $>0,05$ \\
\hline Chi-Square & 0,000 & 0,084 & $\begin{array}{l}X^{2} \text { Statistik }<X^{2} \text { tabel } \\
D F=499 \mathrm{Sig}=0,05, X^{2}=552,07\end{array}$ \\
\hline NFI & 1,000 & 1,000 & Mendekati 1 semakin baik \\
\hline RMS Theta & & 373 & $<0,12$ \\
\hline
\end{tabular}

Sumber: hasil olah data SmartPLS

Pada hasil uji model fit menunjukkan nilai Standarized Root Mean Square Residual (SRMR) memiliki nilai output model sebesar 0,003 yang berarti lebih rendah dari 0,10 sehingga menunjukkan model yang baik guna menghindari misspecification model. Untuk hasil ouput d_ULS dan d_G menujukkan hasil lebih kecil dari 0,05 sehingga menunjukkan bahwa model memiliki kesesuaian yang baik. Chi-square menujukkan hasil 0,084 yang dimana hasil tersebut lebih kecil dari 552,07 yang berarti jumlah variabel manifest dalam model jalur PLS dan jumlah variabel independen dalam 
model matriks kovarian tercukupi. Pada hasil ouput NFI menunjukkan hasil 1 yang berarti menunjukkan kecocokan yang baik atau model yang semakin baik. Untuk RMS_theta mengindikasikan model yang tidak pas pada penelitian ini karena hasil output menunjukkan nilai 0.373 dimana nilai ini lebih dari cut-off value sebesar 0.12 .

\section{Uji Hipotesis}

Berikut adalah model penelitian dari hasil uji hipotesis menggunakan aplikasi SmartPLS

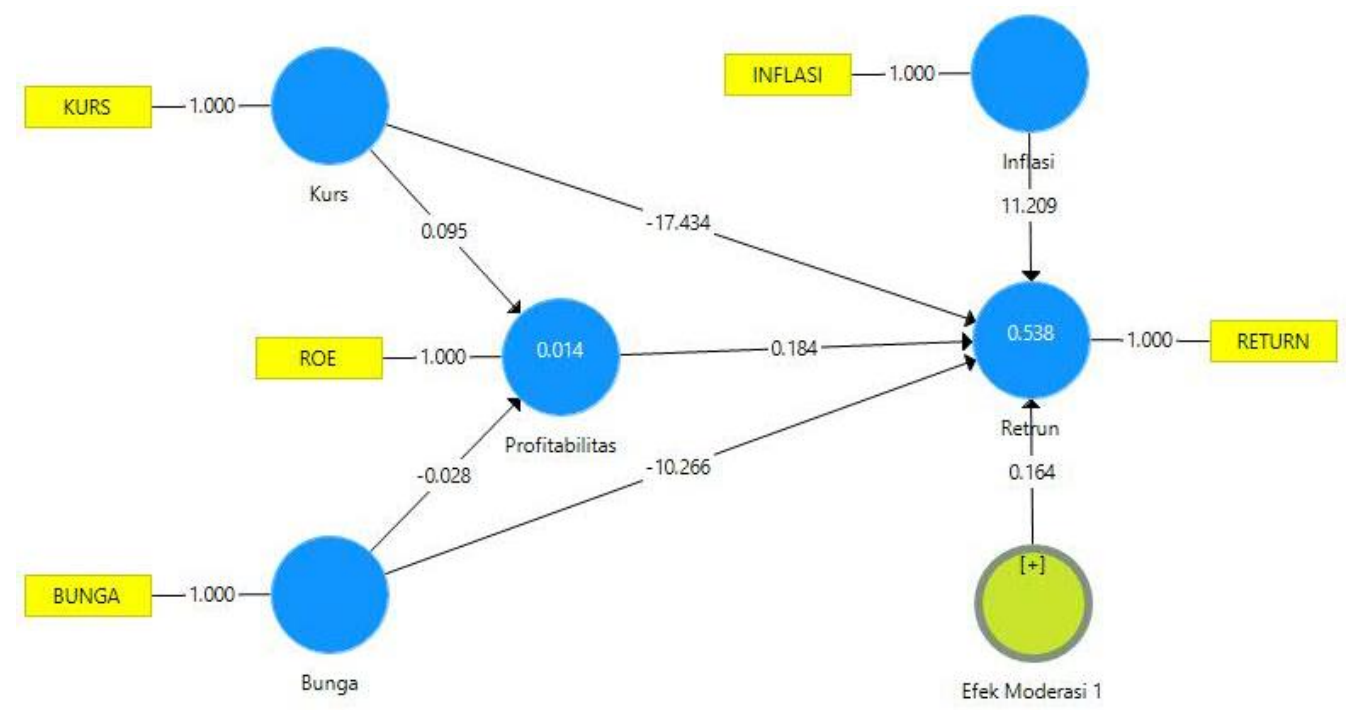

Gambar 1

Model Penelitian setelah Proses Bootstraping

Setelah dilakukan uji bootstrapping dengan menggunakan smartPLS didapatkan hasil nilai path coeficients seperti pada tabel berikut.

Tabel 4

Hasil Uji Hipotesis

\begin{tabular}{llcc}
\hline & Hipotesis & $\begin{array}{c}\text { Koefisien } \\
\text { Parameter }\end{array}$ & P Values \\
\hline H1 & Nilai tukar berpengaruh negatif signifikan terhadap profitabilitas & 0,095 & 0,508 \\
\hline H2 & Suku bunga berpengaruh negatif signifikan terhadap profitabilitas & $-0,028$ & 0,838 \\
\hline H3 & Nilai tukar berpengaruh negatif signifikan terhadap return saham & $-17,43$ & 0,000 \\
\hline H4 & Suku bunga berpengaruh negatif signifikan terhadap return saham & $-10,266$ & 0,583 \\
\hline H5 & Profitabilitas berpengaruh positif signifikan terhadap return saham & 0,184 & 0,038 \\
\hline
\end{tabular}

Sumber: hasil olah data SmartPLS

\section{Nilai Tukar Berpengaruh Negatif Signifikan Terhadap Profitabilitas (H1)}

Hipotesis $\mathrm{H} 1$ nilai koefisien parameter 0,095 yang menunjukkan bahwa nilai tukar (X1) memiliki pengaruh positif terhadap profitabilitas (Y1). Sedangkan P-Value diperoleh nilai 0,508 (lebih dari 0,05). Hal ini menunjukkan bahwa nilai tukar (X1) 
berpengaruh tidak signifikan terhadap profitabilitas (Y1). Dengan demikian hipotesis yang menyatakan bahwa nilai tukar berpengaruh negatif signifikan terhadap profitabilitas tidak terbukti. Hasil penelitian ini sejalan dengan hasil penelitan Adiyadnya et al. (2016) dan Kartikaputri (2018) yang menunjukkan bahwa nilai tukar berpengaruh positif dan tidak signifikan terhadap profitabilitas.

Kenaikan dan penurunan nilai tukar akan berdampak pada perusahaan yang kegiatan produksi perusahaan baik dari bahan baku maupun pemasaran produknya yang mengandalkan sistem ekspor atau impor. Penguatan nilai tukar rupiah akan berdampak positif pada perusahaan berbasis pasar domestik karena dapat mengurangi biaya bahan baku yang diimpor sehingga dapat meningkatkan profitabilitas perushaan. Sedangkan pada perusahaan berbasis ekspor, penguatan nilai tukar rupiah akan berdampak negatif karena perusahaan akan kesulitan (menjadi tidak kompetitif) dalam hal persaingan harga yang berdampak pada pemasaran produknya di luar negeri (penerimaan devisa ekspor akan menurun) sehingga menurunkan profitabiltas perusahaan.

Tidak adanya pengaruh yang signifikan antara nilai tukar terhadap profitabilitas dapat disebabkan karena perusahan sektor consumer goods yang menjadi sampel penelitian tidak mengadalkan penjualan secara ekspor sebagai sumber pendapatan penjualan utamanya. Berdasarkan data pada table 5 mengenai perbandiangan penjualan produk ekspor dan penjualan dalam negeri, didapatkan hasil bahwa rata-rata perusahaan hanya mengandalkan $11 \%$ penjualan ke luar negeri atau ekspor.

\section{Tabel 5}

\begin{tabular}{ccccc}
\multirow{2}{*}{$\begin{array}{c}\text { Daftar Perbandingan Penjualan Dalam Negeri dan Luar Negeri Perusahaan } \\
\text { Sektor Consumer Goods yang Menjadi Sampel Penelitian }\end{array}$} \\
\cline { 3 - 5 } & \multirow{3}{*}{ Kode } & \multicolumn{2}{c}{ Penjualan } & $\begin{array}{c}\text { Presentase } \\
\text { Penjualan } \\
\text { Ekspor }\end{array}$ \\
\cline { 3 - 5 } $\mathbf{1}$ & BUDI & $2,510,034$ & 215,832 & $8 \%$ \\
\hline $\mathbf{2}$ & CEKA & $6,163,588,492$ & $33,685,257$ & $1 \%$ \\
\hline $\mathbf{3}$ & CLEO & - & - & - \\
\hline $\mathbf{4}$ & CINT & $309,995,521,460$ & $20,680,165,559$ & $6 \%$ \\
\hline $\mathbf{5}$ & DLTA & $585,099,597$ & $1,129,945$ & $0 \%$ \\
\hline $\mathbf{6}$ & GGRM & $112,568,242$ & $1,909,069$ & $2 \%$ \\
\hline $\mathbf{7}$ & HMSP & $92,206,629$ & 218,581 & $0.2 \%$ \\
\hline $\mathbf{8}$ & ICBP & $38,275,273$ & $8,365,775$ & $18 \%$ \\
\hline $\mathbf{9}$ & INDF & $69,340,714$ & $12,390,755$ & $15 \%$ \\
\hline $\mathbf{1 0}$ & KAEF & $9,783,068,029$ & $223,104,994$ & $2 \%$ \\
\hline $\mathbf{1 1}$ & KLBF & $22,000,272,615,849$ & $1,112,382,375,375$ & $5 \%$ \\
\hline $\mathbf{1 2}$ & KICI & $72,186,433,920$ & $15,781,550,688$ & $18 \%$ \\
\hline $\mathbf{1 3}$ & MBTO & $31,367,148,540$ & $12,633,984,704$ & $29 \%$ \\
\hline
\end{tabular}




\begin{tabular}{ccccc}
\hline $\mathbf{1 4}$ & MERK & $618,355,839$ & $37,491,286$ & $6 \%$ \\
\hline $\mathbf{1 5}$ & MLBI & 196,925 & 15,752 & $7 \%$ \\
\hline $\mathbf{1 6}$ & MYOR & $1,438,009,525,738$ & $1,011,373,124,826$ & $41 \%$ \\
\hline $\mathbf{1 7}$ & PEHA & $879,228,032$ & $101,328,621$ & $10 \%$ \\
\hline $\mathbf{1 8}$ & RMBA & - & - & - \\
\hline $\mathbf{1 9}$ & ROTI & - & - & - \\
\hline $\mathbf{2 0}$ & SIDO & - & - & - \\
\hline $\mathbf{2 1}$ & TCID & $1,369,683,859,399$ & $619,322,134,188$ & $31 \%$ \\
\hline $\mathbf{2 2}$ & TSPC & $10,604,218,170,441$ & $364,183,919,805$ & $3 \%$ \\
\hline $\mathbf{2 3}$ & UNVR & $41,158,401$ & $1,814,073$ & $4 \%$ \\
\hline & \multicolumn{5}{c}{} & $11 \%$
\end{tabular}

Sumber: laporan keuangan tahunan

\section{Suku bunga berpengaruh negatif signifikan terhadap profitabilitas (H2)}

Pada Hipotesis H2 didapatkan nilai koefisien parameter 0,028 yang berarti bahwa suku bunga (X2) memiliki pengaruh positif terhadap profitabilitas (Y1). Sedangkan PValue diperoleh nilai 0,838 (lebih dari 0,05). Hal ini menunjukkan bahwa suku bunga (X2) berpengaruh tidak signifikan terhadap profitabilitas (Y1). Jadi hipotesis yang menyatakan bahwa suku bunga berpengaruh positif signifikan terhadap profitabilitas tidak terbukti. Hasil ini sejalan dengan hasil penelitan Zuchrinata \& Yunita (2019) dan Khotijah et al. (2020) yang menunjukkan bahwa suku bunga berpengaruh negatif dan tidak signifikan terhadap profitabilitas.

Menurut teori trade off, perusahaan dapat meningkatkan profitabilitasnya dengan menggunakan utang karena bunga dapat mengurangkan pajak. Namun jika semakin tinggi utang maka akan semakin tinggi bunga utang sehingga dapat memunculkan risiko gagal bayar, kesulitan keuangan dan kebangkrutan (Modigliani \& Miller, 1958). Dari teori ini dapat dilihat bahwa adanya suku bunga dapat menambah atau mengurangi profitabilitas tergantung pengelolaan dan proporsi hutang perusahaan.

Hasil peneltian ini yang menujukkan pengaruh suku bunga terhadap profitabilitas yang tidak signifikan. Jika dilihat dari laporan keuangan, terdapat 15 dari 23 perusahaan yang melaporkan penggunaan hutang bank pada laporan neraca (tabel 6). Dari 15 perusahaan tersebut rata-rata $25 \%$ total kewajibannya merupakan hutang bank. Rendahnya presentase ini menyebabkan kenaikan atau penurunan suku bunga Bank Indonesia tidak mempengaruhi profitabilitasnya. Selain itu beban bunga yang timbul dari adanya hutang bisa menurunkan dan meningkatkan profitabilitas tergantung pada bagaimana perusahaan mengelolanya sehingga tinggi rendahnya hutang tidak selalu berpengaruh terhadap profitabilitas. 
Dampak Makro Ekonomi Terhadap Return Saham dengan Profitabilitas Sebagai Intervening dan Inflasi Sebagai Moderasi

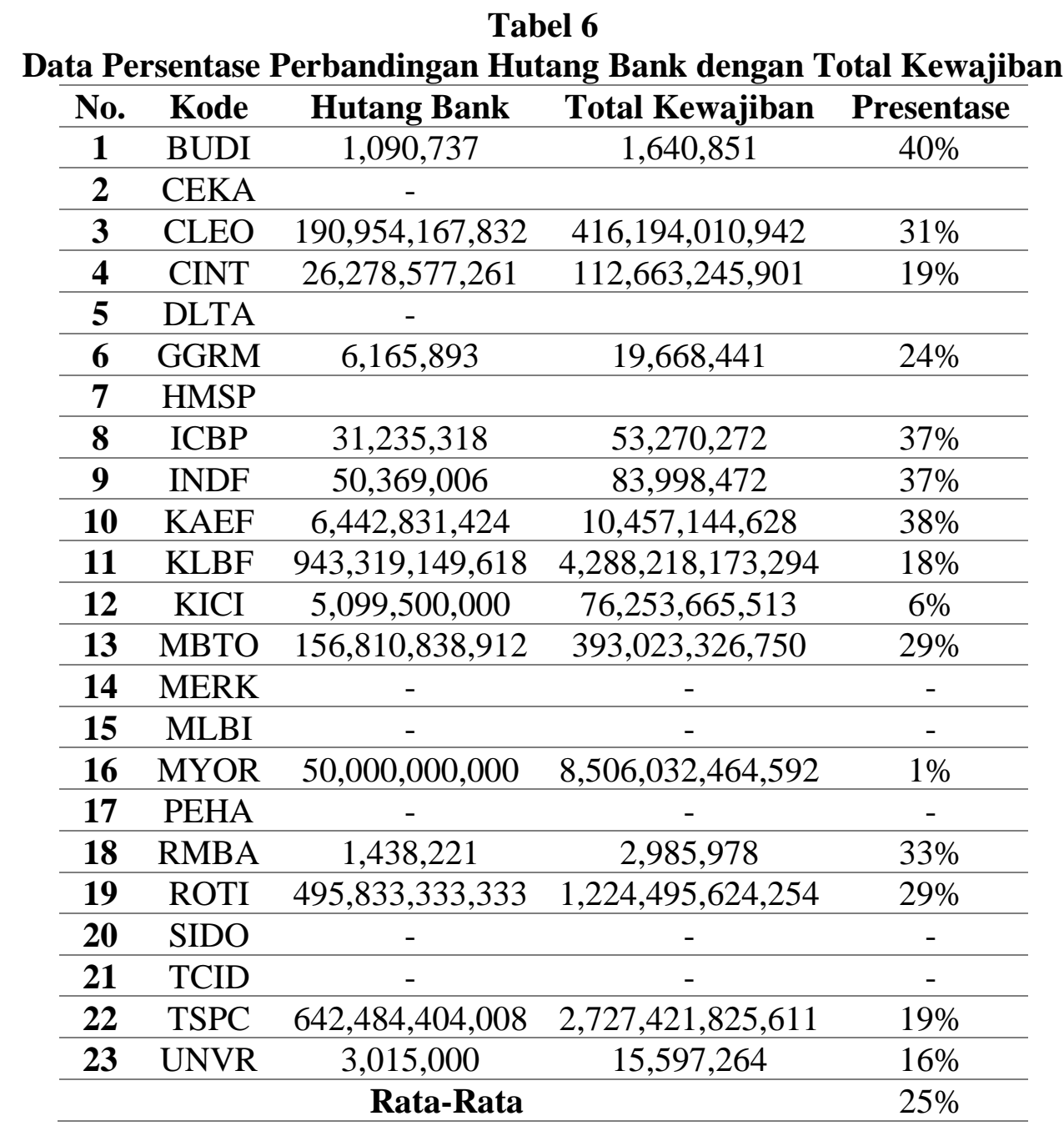

Sumber: Laporan keuangan perusahaan

\section{Nilai Tukar Berpengaruh Negatif Signifikan Terhadap Return Saham}

Nilai koefisien parameter hipotesis $\mathrm{H} 3$ adalah -17,434 yang menunjukkan bahwa nilai tukar (X1) memiliki pengaruh positif terhadap return saham (Y2). Sedangkan PValue diperoleh nilai 0,000 (kurang dari 0,05). Hal ini menunjukkan bahwa nilai tukar (X1) berpengaruh signifikan terhadap return saham (Y2). Dengan demikian hipotesis yang menyatakan bahwa nilai tukar berpengaruh negatif signifikan terhadap return saham terbukti. Temuan ini sejalan dengan hasil penelitian terdahulu yang dilakukan oleh Khan (2019) serta Hakim \& Martono (2019). Kesimpulan dari penelitian keduanya menunjukan hasil bahwa nilai tukar berpengaruh negatif signifikan terhadap return saham .

Fluktuasi nilai tukar rupiah akan berdampak pada perekonomian. Dampak dari kenaikan nilai tukar rupiah adalah kenaikan harga komoditas di sektor riil, berkurangnya simpanan dalam negeri, dan banyak dampak lainnya (Akbar \& Afiezan, 2018). Hal ini 
akan menyebabkan daya beli masyarakat menurun dan kemungkinan besar investor akan menarik dananya untuk memenuhi kebutuhannya. Penurunan investasi di pasar modal akan menyebabkan harga saham turun. Penurunan harga saham berarti penurunan return saham bagi investor.

\section{Suku bunga berpengaruh negatif signifikan terhadap return saham}

Pada Hipotesis H4 didapatkan nilai koefisien parameter -10,266 yang berarti bahwa suku bunga (X2) memiliki pengaruh positif terhadap return saham (Y2). Sedangkan P-Value diperoleh nilai 0,000 (kurang dari 0,05). Hal ini menunjukkan bahwa suku bunga (X2) berpengaruh signifikan terhadap return saham (Y2). Jadi hipotesis yang menyatakan bahwa suku bunga berpengaruh negatif signifikan terhadap return saham terbukti. Hasil penelitian ini sejalan dengan penelitian terdahulu yang dilkaukan oleh Al-Abdallah \& Aljarayesh (2017) serta Siregar \& Diana (2019) yang menunjukkan bahwa suku bunga berpengaruh signifikan negatif terhadap return saham. Penelitian keduanya menyimpulkan bahwa semakin tinggi suku bunga, semakin rendah return saham yang diterima investor.

Tingkat suku bunga merupakan salah satu indikator dalam menentukan apakah seseorang akan melakukan investasi atau menabung. Turunnya tingkat suku bunga dapat menarik investor untuk berinvestasi pada saham dibandingkan dengan investasi bebas risiko seperti deposito dengan harapan mendapat return yang lebih tinggi (Shuangqun, 2017). Hal ini menyebabkan kenaikan minat investasi pada saham. Peningkatan permintaan saham akan berdampak pula pada kenaikan harga saham yang kemudian akan berdampak pada peningkatan return saham (Akbar \& Afiezan, 2018).

\section{Profitabilitas Berpengaruh Positif Signifikan Terhadap Return Saham}

Nilai koefisien parameter hipotesis H5 adalah 0.184 yang menunjukkan bahwa profitabilitas (Y1) memiliki pengaruh positif terhadap return saham (Y2). Sedangkan PValue diperoleh nilai 0,038 (kurang dari 0,05). Hal ini menunjukkan bahwa profitabilitas (Y1) berpengaruh signifikan terhadap return saham (Y2). Dengan demikian hipotesis yang menyatakan bahwa profitabilitas berpengaruh positif signifikan terhadap return saham terbukti. Hasil penelitian ini sejalan dengan penelitian terdahulu yang dilkaukan oleh Sugito et al. (2019) serta Almira \& Wiagustini (2020) yang menunjukkan bahwa profitabilitas berpengaruh signifikan positif terhadap return saham. Penelitian keduanya menyimpulkan bahwa semakin tinggi profitabilitas yang diproksikan dengan rasio ROE, semakin tinggi pula return saham yang diterima oleh investor.

Menurut signalling theory, jika informasi dari perusahaan direspon dengan positif oleh pasar maka nilai perusahaan akan meningkat, namun jika ternyata respon itu negatif maka nilai perusahaan akan turun. Perusahaan yang mampu menghasilkan dan meningkatkan laba merupakan informasi positif dari perusahaan karena dianggap bahwa perusahaan memiliki prospek yang bagus untuk masa depan. Hal ini akan direspon oleh 
pasar secara positif. Respon yang positif tersebut dapat diperlihatkan dengan kenaikan harga saham perusahaan. Kenaikan harga saham akan meningkatkan return saham.

\section{Analisis Mediasi}

Analisis mediasi dilakukan dengan menganalisis hasil output statistik yang meliputi direct effect, indirect effect, dan total effect. Dari kalkulasi bootstraping, didapatkan hasil sebagai berikut:

\section{Tabel 7}

Hasil Analaisis Mediasi

\begin{tabular}{lcccccr}
\hline \multirow{1}{*}{$\begin{array}{l}\text { Fungsi } \\
\text { Endogen }\end{array}$} & \multicolumn{5}{c}{ Return Saham (Y2) } \\
\cline { 2 - 7 } & Koefisien & $\begin{array}{c}\text { P- } \\
\text { Value }\end{array}$ & Koefisien & $\begin{array}{c}\text { P- } \\
\text { Value }\end{array}$ & Koefisien & P- \\
Fungsi Eksogen & & & & & Value \\
\hline $\begin{array}{l}\text { 1. Nilai Tukar } \\
\text { (X1) }\end{array}$ & $-17,234$ & 0,000 & 0.018 & 0,526 & $-17,416$ & 0,000 \\
\hline $\begin{array}{l}\text { 2. Suku Bunga } \\
\text { (X2) }\end{array}$ & $-10,266$ & 0,000 & $-0,005$ & 0,855 & $-10,271$ & 0,000 \\
& & & & & & \\
\end{tabular}

Sumber: Hasil Olah data SmartPLS

Pada hasil analisis mediasi pengaruh nilai tukar terhadap return saham melalui profitabilitas didaptkan nilai koefisien total effect sebesar -17,416 lebih kecil dari nilai koefisien direct effect sebesar -17,234 maka variabel intervening dikatakan memberikan efek penurunan. Namun nilai p-value indirect effect menunjukkan hasil 0,526 (lebih besar dari 0,05$)$ sehingga variabel intervening tidak mampu memediasi secara signifikan. Dari kedua hasil analisis tersebut maka variabel intervening (profitabilitas) secara tidak signifikan memberikan efek penurunan pada pengaruh antara nilai tukar terhadap retun saham. Hasil perhitungan ini sejalan dengan penelitan yang dilakukan oleh Kartikaputri (2018) dan Munthe (2018). Hasil penelitian keduanya menyimpulkan bahwa profitabilitas tidak mampu memediasi pengaruh nilai tukar terhadap return saham

Pada kondisi perekonomian yang kurang stabil sperti saat pandemi covid-19 ini faktor makro ekonomi lebih dapat berpengaruh pada harga saham. Pelemahan nilai tukar Rupiah terhadap Dollar Amerika langsung direspon negatif oleh para pelaku pasar dengan aksi jual di bursa saham dan pasar obligasi yang terjadi sejak bulan Februari 2020, dan semakin masif di bulan Maret 2020 ketika kasus pertama Covid-19 diumukan di Indonesia dan ditambah dana asing masih pergi dari pasar Indonesia (Kartikaningsih et al., 2020). Namun pelemahan nilai tukar rupiah tidak berpengaruh terhadap profitabilitas karena presentase penggunaan ekspor dan impor bukan yang dominan dalam operasional perusahaan sehingga profitabilitas tidak mampu memberikan efek peningkatan pada return saham. Disamping itu, investor lebih cepat merespon informasi pasar yang diperbarui setiap 
hari seperti informasi nilai tukar sebagai dasar pengambilan keputusan investasi dibanding profitabilitas yang laporannya baru bisa dilihat per triwulan.

Pada hasil analisis mediasi pengaruh suku bunga terhadap return saham melalui profitabilitas didapatkan nilai koefisien total effect sebesar -10,271 lebih kecil dari nilai koefisien direct effect sebesar -10,266 maka variabel intervening dikatakan memberikan efek penurunan. Namun nilai p-value indirect effect menunjukkan hasil 0,855 (lebih besar dari 0,05) sehingga variabel intervening tidak mampu memediasi secara signifikan. Dari kedua hasil analisis tersebut maka variabel intervening (profitabilitas) secara tidak signifikan memberikan efek penurunan pada pengaruh antara suku bunga terhadap retun saham. Hasil perhitungan ini sejalan dengan penelitan yang dilakukan oleh Zakiyah (2019) dan Munthe (2018). Hasil penelitian keduanya menyimpulkan bahwa profitabilitas tidak mampu memediasi pengaruh suku bunga terhadap return saham.

Suku bunga yang menurun tidak mampu meningkatkan profitabilitas perushaan karena presentase penggunaan hutang perusahaan consumer goods yang menjadi sampel penelitian hanya $25 \%$ dan 8 dari 23 perusahaan tidak menggunakan hutang bank sehingga mereka tidak memiliki kewajiban membayar bunga pinjaman bank.

Suku bunga berubah atas dasar tanggapan pemerintah untuk membentuk kebijakan moneter yang dimaksudkan untuk memberi stimulus di tengah kondisi ekonomi yang terpuruk agar dapat kembali normal. Informasi ini dinggap lebih penting bagi investor saat masa krisis ekonomi dibandingkan dengan profitabilitas perusahaan. Penurunan suku bunga ini merupakan informasi positif bagi investor karena saham menjadi lebih menarik saat suku bunga bebas risiko menurun sehingga para investor akan beralih berinvestasi pada saham dengan harapan memperoleh return yang lebih tinggi.

\section{Analisis Moderasi}

Hasil analisis interaksi akan dapat menentukan seberapa besar peran variabel moderasi dalam memperkuat atau memperlemah variabel independen untuk mempengaruhi variabel dependen. Dari kalkulasi bootstraping, didapatkan hasil sebagai berikut:

\begin{tabular}{lcc}
\multicolumn{3}{c}{ Tabel 8 } \\
\multicolumn{1}{c}{ Hasil Output Analisis Moderasi } \\
\hline \multicolumn{1}{c}{ Interaksi } & Koefisien & P Values \\
\hline $\begin{array}{l}\text { Moderating } \text { effect } \text { profitabilitas } \\
\text {-> return }\end{array}$ & 0,164 & 0,120 \\
\hline Profitabilitas -> return & 0,184 & 0,038 \\
\hline
\end{tabular}

Sumber: Hasil Olah data SmartPLS

Pada hasil interaksi moderating effect profitabilitas terhadap return saham didapatkan nilai koefisien sebesar 0,164 lebih kecil (mengalami penurunan) dari nilai koefisien direct effect profitabilitas terhadap return saham sebesar 0.184 . Hal ini berarti variabel moderating dikatakan memperlemah pengaruh profitabilitas terhadap return 
saham. Kemudian, nilai p-value moderating effect menunjukkan hasil 0,120 (lebih besar dari 0,05) sehingga variabel moderating dapat dikatakan memoderasi secara tidak signifikan. Dari kedua hasil analisis tersebut maka variabel moderating (inflasi) secara tidak signifikan meperlemah pengaruh antara profitabilitas terhadap retun saham. Hasil penelitian ini sesuai dengan peneliti terdahulu yang dilakukan oleh Misbahudin et al. (2020) dan Noviyah (2018). Penelitian keduanya menyimpulkan bahwa inflasi tidak mampu memoderasi pengaruh profitabilitas terhadap return saham.

Dari hasil penelitian dapat dinyatakan bahwa para investor lebih fokus melihat profitabilitas perusahaan dalam menetukan investasinya tanpa melihat tingkat inflasi yang terjadi pada waktu yang bersamaan. Penurunan inflasi yang terjadi pada tahun 2020 tidak menyebabkan biaya produksi mengalami penurunan karena pada kenyataanya inflasi yang terjadi merupakan akibat dari melambannya perkenomian karena pembatasan kegiatan selama pandemi covid-19. Kenaikan beberapa komoditas barang, kenaikan biaya impor dan adanya pembatasan ekspor, serta kenaikan biaya distribusi yang terjadi justru terjadi pada saat adanya penurunan inflasi dan berakibat pada penurunan profitabilitas. Hal inilah yang menyebabkan investor lebih melihat tingkat kemmapuan perusahaan menghasilkan profit dibandingkan tingkat inflasi.

\section{Kesimpulan}

Berdasarkan hasil analisis dan pembahasan yang telah dijelaskan pada bagian pembahasan sebelumnya, maka kesimpulan dari penelitian ini nilai tukar berpengaruh positif dan tidak signifikan terhadap profitabilitas. Hal ini disebabkan karena perusahan sektor consumer goods tidak mengandalkan penjualan secara ekspor sebagai sumber pendapatan penjualan utamanya. Kenaikan dan penurunan nilai tukar akan berdampak pada perusahaan yang kegiatan produksi perusahaan baik dari bahan baku maupun pemasaran produknya yang mengandalkan sistem ekspor atau impor. Suku bunga berpengaruh negatif dan tidak signifikan terhadap profitabilitas. Hal ini disebabkan karena terdapat beberapa perusahaan yang tidak menggunakan hutang bank sehingga kenaikan atau penurunan suku bunga Bank Indonesia tidak memengaruhi profitabilitasnya. Selain itu beban bunga yang timbul dari adanya hutang bisa menurunkan dan meningkatkan profitabilitas tergantung pada bagaimana perusahaan mengelolanya sehingga tinggi rendahnya hutang tidak selalu berpengaruh terhadap profitabilitas. Nilai tukar berpengaruh negatif signifikan terhadap return saham. Dampak dari melemahnya nilai tukar rupiah adalah kenaikan harga komoditas di sektor riil, berkurangnya simpanan dalam negeri, dan banyak dampak lainnya. Hal ini akan menyebabkan daya beli masyarakat menurun dan kemungkinan besar investor akan menarik dananya untuk memenuhi kebutuhannya. Penurunan investasi akan menurunkan tingkat return saham. Suku bunga berpengaruh negatif signifikan terhadap return saham. Turunnya tingkat suku bunga dapat menarik investor untuk berinvestasi pada saham dibandingkan dengan investasi bebas risiko seperti deposito dengan harapan 
mendapat return yang lebih tinggi. Hal ini menyebabkan kenaikan minat investasi pada saham. Peningkatan permintaan saham akan berdampak pula pada kenaikan harga saham yang kemudian akan berdampak pada peningkatan return saham. Profitabilitas berpengaruh positif signifikan terhadap return saham. Perusahaan yang mampu menghasilkan dan meningkatkan laba merupakan informasi positif dari perusahaan karena dianggap bahwa perusahaan memiliki prospek yang bagus untuk masa depan. Hal ini akan direspon oleh pasar secara positif. Respon yang positif tersebut dapat diperlihatkan dengan kenaikan harga saham perusahaan. Kenaikan harga saham akan meningkatkan return saham. Profitabilitas tidak mampu memediasi pengaruh nilai tukar dan suku bunga terhadap return saham. Hal ini disebabkan karena pada masa pandemi covid-19, faktor makro ekonomi lebih cepat berubah dan perubahan terjadi hampir setiap hari sehingga informasi ini lebih menarik untuk dijadikan dasar pengambilan keputusan dibanding profitabilitas yang baru dapat dilihat datanya pada tiap triwulan. Inflasi tidak mampu memoderasi pengaruh profitabilitas terhadap return saham. Penurunan inflasi yang terjadi pada tahun 2020 tidak menyebabkan penurunan biaya produksi karena pada kenyataanya inflasi yang terjadi merupakan akibat dari melambannya perkenomian karena pembatasan kegiatan selama pandemi covid-19 sehingga inflasi tidak dapat memperkuat pengaruh profitabilitas terhadap return saham. 
Dampak Makro Ekonomi Terhadap Return Saham dengan Profitabilitas Sebagai

Intervening dan Inflasi Sebagai Moderasi

\section{BIBLIOGRAFI}

Adiyadnya, I. N. S., Artini, L. G. S., \& Rahyuda, H. (2016). Pengaruh Beberapa Variabel Ekonomi Makro Terhadap Profitabilitas dan Return Saham Pada Industri Perbankan Di BEI. E-Jurnal Ekonomi Dan Bisnis Universitas Udayana, 5(8), 2579-2608. https://finance.detik.com/berita-ekonomi-bisnis/d-4957376/begini-virus-coronalumpuhkan-ekonomi-ri Google Scholar

Akbar, T., \& Afiezan, A. (2018). Determination Of Sharia Stock Price Through Analysis Of Fundamental Factors And Macro Economic Factors. Account And Financial Management Journal, 03(10), 1739-1745. Google Scholar

Almira, N. P. A. K., \& Wiagustini, N. L. P. (2020). Return on Asset, Return on Equity, Dan Earning Per Share Berpengaruh Terhadap Return Saham. E-Jurnal Manajemen Universitas Udayana, 9(3), 1069. Google Scholar

Al-Abdallah, S. Y. (2017). Influence Of Interest Rate , Exchange Rate And Inflation On Common Stock Returns Of Amman Stock Exchange , Jordan. International Journal Of Economics, Commerce And Management, V(10), 589-601. Google Scholar

Alam, Q. N. (2020). Impacts Of Macroeconomic Variables On The Stock Market Returns Of South Asian Region. Canadian Journal Of Business And Information Studies, 2(2), 24-34. Google Scholar

Fadlilah, M. A., \& Hermuningsih, S. (2017). Pengaruh Nilai Tukar Dan Harga Minyak Mentah Dunia Terhadap Return Saham Pt. Indomobil Sukses Internasional Tbk. Dan Pt. Astra Internasional Tbk. Tahun 2006-2016. Manajemen Dewantara, 1(2), 25-37. Google Scholar

Fauzia, M. (2021). Inflasi 2020 1,68 Persen, Terendah Sepanjang Sejarah. Kompas. Https://Amp.Kompas.Com/Money/Read/2021/01/04/125828426/Inflasi-2020-168Persen-Terendah-Sepanjang-Sejarah

Hakim, L., \& Martono, M. (2019). Fundamental Role Of Macro And Microeconomics To Profitability And The Implications On Stock Return: Evidence From Banking Companies On The Indonesia Stock Exchange. International Journal Of Economics And Financial Issues, 9(6), 84-93. Google Scholar

Hendrawan, R., \& Avitianti, A. (2018). Ltv, Macro Economics And Roe To Stock Return In Real Estate And Property Companies Listed On Lq 45 Period 2009 - 2017. International Journal Of Engineering \& Technology, 7(4.38), 852.

Henseler, J., Hubona, G., \& Ray, P. A. (2016). Using Pls Path Modeling In New Technology Research: Updated Guidelines. Industrial Management And Data Systems, 116(1), 2-20. Google Scholar

Syntax Literate, Vol. 6, No. 12, Desember 2021 
Rizki Wulandari, Sri Hermuningsih, Gendro Wiyono

Hermuningsih, S. (2019). The Effect Of Macroeconomic Fundamentals On The Financial Performance With Deposits As Intervening Variables: A Case Study Of Sharia Banks In Indonesia. Jurnal Maksipreneur: Manajemen, Koperasi, Dan Entrepreneurship, 8(2), 165. Google Scholar

Hermuningsih, S., Rahmawati, A. D., \& Mujino. (2018). Faktor-Faktor Yang Mempengaruhi Return Saham. Ekobis, 13(1), 39-56.

Junaedi, D., Arsyad, M. R., Norman, E., Romli, M., \& Salistia, F. (2020). Dampak Pandemi Covid-19 Terhadap Stabilitas Moneter Indonesia. Al-Kharaj: Jurnal Ekonomi, Keuangan \& Bisnis Syariah, 3(1), 17-36. Google Scholar

Kartukaputri, R. (2018). Pengaruh Inflasi dan Nilai Tukar terhadap Return Saham dengan Profitabilitas sebagai Variabel Intervening pada Perusahaan property dan Real Estate yang Terdaftar di Bursa Efek Indonesia Tahun 2013-2016. Jurnal Ekobis Dewantara, 1(8), 132-142. Google Scholar

Kartikaningsih, D., Nugraha, \& Sugiyanto. (2020). Pengaruh Nilai Tukar Terhadap Harga Saham Sektor Infrastruktur Pada Masa Pandemi Covid-19. Jurnal Akuntansi Dan Keuangan, 3(1), 53-60. Google Scholar

Khan, M. (2019). Impact Of Exchange Rate On Stock Returns In Shenzhen Stock Exchange: Analysis Through Ardl Approach. International Journal Of Economics And Management, 1(2), 15-26. Google Scholar

Misbahudin, D., Ahmar, N., \& Wiratno, A. (2020). Peran Inflasi Dalam Memoderasi

Return Saham Dan Industri Dasar Kimia. JIsEB, 1(1), 13-23. Google Scholar

Modigliani, F., \& Miller, M. (1958). The Cost Of Capital , Corporation Finance And The Theory Of Investment Franco Modigliani; Merton H . Miller. The American Economic Review, 48(3), 261-297. Google Scholar

Munthe, K. (2018). Pengaruh Variabel Makro Ekonomi terhadap Harga Saham dengan Profitabilitas sebagai Variabel Intervening pada Perusahaan manufaktur di Bursa Efek Indonesia. Universitas Katolik Santo Thomas Medan, 53(9), 1689-1699. Google Scholar

Noviyah, N. M. R. (2018). Pengaruh Profitabilitas, Likuiditas, Dan Solvabilitas Terhadap Harga Saham Perbankan Dengan Inflasi Sebagai Variabel Moderating Pada Periode 2007-2015. Jurnal Manajemen Dan Bisnis Indonesia, 5(2), 133-148. Google Scholar

Saputri, R. S., Ruwanti, S., \& Adel, J. F. (2019). Pengaruh Nilai Tukar Dan Suku Bunga Terhadap Return Saham Dengan Profitabilitas Sebagai Variabel Intervening Pada Perusahaan Manufaktur Yang Terdaftar Dibursa Efek Indonesia Tahun 2015-201. 3(1), 346-365. Google Scholar

Shuangqun, L. (2017). Research On The Relationship Between Interest Rate And Stock 
Price In China. International Journal Of Science And Research (Ijsr), 6(7), 20932099. Google Scholar

Siregar, E. I., \& Diana. (2019). The Impact Of Political Risk And Macro Economics On Stock Return At Indonesia Stock Exchange (An Approach Of Arbritage Pricing Theory (Apt)). Kne Social Sciences Icema International Conference On Economics, Management, And Accounting, 2019, 744-772. Google Scholar

Sugito, P., Noormansyah, I., \& Nursanita, N. (2019). The Influence of Profitability on Stock Return with Inflation as a Moderating Variable (Empirical Study on Automotive Companies and Components Listed in Indonesia Stock Exchange 2013-2017). Annual International Conference on Accounting Research, 127(Aicar 2019), 86-92. Google Scholar

Suriyani, N. K., \& Sudiartha, G. M. (2018). Pengaruh Tingkat Suku Bunga, Inflasi Dan Nilai Tukar Terhadap Return Saham Di Bursa Efek Indonesia. E-Jurnal Manajemen Universitas Udayana, 7(6), 255328. Google Scholar

Wicaksono, A. (2020, May 7). Menko Pmk Sebut Krisis Ekonomi Saat Ini Lebih Parah Dari 1998. 500918. Https://Www.Cnnindonesia.Com/Nasional/2020050704575620-500918/Menko-Pmk-Sebut-Krisis-Ekonomi-Saat-Ini-Lebih-Parah-Dari-1998

Wiska, M., \& Resty, F. (2020). Dampak Inflasi, Tingkat Suku Bunga Dan Nilai Tukar Terhadap Return Saham Pada Perusahaan Farmasi Yang Terdaftar Di Bursa Efek Indonesia (Bei). International Journal Of Management And Business, 1 (November), 111-117. Https://Brage.Bibsys.No/Xmlui/Handle/11250/216770

Wiyono, G. (2020). Menrancang Penelitian Bisnis dengan Alat Analisis SPSS 25 \& SmartPLS 3.2.8. STIM YKPN.

Zakiyah, T. (2019). Pengaruh Faktor-faktor Ekonomi Makro Terhadap Return Saham Dengan Profitabilitas Sebagai Variabel Intervening Pada Perusahaan Perbankkan Peraih Indonesia Banking Award (IBA) Tahun 2018. Jurnal BAABU AL-ILMI: Ekonomi Dan Perbankan Syariah, 4(1), 89. Google Scholar

\section{Copyright holder:}

Rizki Wulandari, Sri Hermuningsih, Gendro Wiyono (2021)

First publication right:

Syntax Literate: Jurnal Ilmiah Indonesia

This article is licensed under:

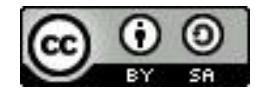

